\title{
Detection of left ventricular thrombi by computerised tomography A preliminary report
}

\author{
C K NAIR, M H SKETCH, P D MAHONEY, J D LYNCH, A N MOOSS, \\ N P KENNEY
}

\begin{abstract}
From the Division of Cardiology and Department of Radiology, Creighton University School of Medicine, Omaha, Nebraska, USA
\end{abstract}

SUMMARY In order to investigate the potential of computerised tomography in the detection of left ventricular mural thrombi, 16 patients suspected of having left ventricular mural thrombi were studied. All patients had suffered transmural myocardial infarction. Fifteen patients had a ventricular aneurysm. One had had systemic emboli. The mean length of time between the myocardial infarction and the study was 14.8 months, with a range of one month to 79 months. All patients underwent computerised tomography of the heart, $M$-mode echocardiography ( $M$-mode), and two-dimensional echocardiography (2-D). Eight patients underwent left ventricular cineangiography. Five patients had surgical confirmation. Computerised tomography, two-dimensional, and $\mathrm{M}$-mode echocardiography predicted left ventricular mural thrombi in 10, eight, and one of the 16 patients, respectively. Left ventricular cineangiography predicted left ventricular mural thrombi in four of the eight patients. Both computerised tomography and left ventricular cineangiography correctly predicted the presence or absence of left ventricular thrombi in all five patients who underwent operation. In the same group, however, twodimensional and M-mode echocardiography failed to predict the presence of thrombi in one and three patients, respectively. Among the 11 patients without surgical confirmation, one, in whom no left ventricular thrombi were shown by $M$-mode and two-dimensional echocardiography, was found to have thrombi on computerised tomography. In another, two-dimensional echocardiography was positive but this finding was not confirmed either by computerised tomography or by left ventricular angiography. Thus, computerised tomography appears to be a promising non-invasive technique and further studies of larger numbers of patients shown to have left ventricular thrombi at operation are indicated.

At necropsy, the reported incidence of left ventricular mural thrombi is between 20 and 60 per cent. ${ }^{1-4}$ Eighty to 90 per cent of systemic emboli originate in the heart. ${ }^{5-7}$ With a 3 to 5 per cent incidence of systemic emboli, left ventricular mural thrombi are an important complication of acute myocardial infarction..$^{49}$ A reliable, preferably non-invasive, method of diagnosis would be valuable. Except in a few cases, $M$-mode echocardiography has proved unsatisfactory..$^{10-14}$ It was hoped that two-dimensional echocardiography, with its ability to visualise the entire left ventricle including the cardiac apex, would provide a reliable

method of diagnosis, ${ }^{15-18}$ and a number of reports have appeared. ${ }^{19-22}$ Unfortunately, early expectations have not been confirmed. In a series reported by Silverman and Schiller, ${ }^{18}$ two-dimensional echocardiography clearly identified only 50 per cent of cases angiographically and surgically proven. In another series, Meltzer et al. ${ }^{21}$ studied 16 patients; their results disclosed two false-negatives and one false-positive.

Computerised tomography is a relatively new diagnostic tool which has been rapidly gaining in popularity in the diagnosis of disorders of the brain and other organs. Computerised tomography gives a complete cross-sectional display without overlap of superimposed structures. The quality of the image is usually excellent because of the lack of 
scattered radiation. Very subtle differences in attenuation of $x$-radiation (and hence density) of structures can be identified. As yet, the technique has not been applied extensively to the heart because of the necessary long scan time enforced by cardiac motion. In the past few years more rapid scanners have been developed. These have brought the era of cardiac computerised tomography closer to realisation. This study reports our early experience in detecting left ventricular mural thrombi using this technique.

\section{Patients and methods}

Sixteen patients were studied (Table 1). All had suffered transmural myocardial infarctions (12 anterior and four inferior). The mean length of time between infarction and study was 14.8 months, with a range of one month to 79 months. Fifteen patients were suspected of having left ventricular mural thrombi because of ventricular aneurysms. The remaining patient was suspected of having a mural thrombus because he had had systemic

Table 1 Clinical, endocardiographic, computerised tomographic, angiographic, and surgical findings

\begin{tabular}{|c|c|c|c|c|c|c|}
\hline $\begin{array}{l}\text { Case } \\
\text { no. }\end{array}$ & Age/sex & Presentation & Time and type of $M I$ & M-mode echo & Two-dimensional echo & Computerised tomograptuㅐ, \\
\hline 1 & $49 / M$ & Chest pain & 3/79-Anterior & $\begin{array}{l}\text { Decreased septal excursion; } \\
\text { decreased LVF; no } \\
\text { thrombus }\end{array}$ & $\begin{array}{l}\text { Anteroapical aneurysm } \\
\text { with thrombus }\end{array}$ & 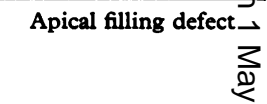 \\
\hline 2 & $57 / M$ & Chest pain & 9/79-Anterior & $\begin{array}{l}\text { Decreased LVF with septal } \\
\text { excursion; no thrombus }\end{array}$ & $\begin{array}{l}\text { Anteroapical aneurysm } \\
\text { with apical thrombus }\end{array}$ & Apical filling defect $\underset{\oplus}{\stackrel{\infty}{\rightleftarrows}}$ \\
\hline 3 & $67 / M$ & Chest pain, CHF & 8/79-Anterior & $\begin{array}{l}\text { LVE with possible apical } \\
\text { aneurysm; no thrombus }\end{array}$ & $\begin{array}{l}\text { Anteroapical aneurysm; } \\
\text { no thrombus }\end{array}$ & Apical filling defect \\
\hline 4 & $51 / M$ & Chest pain & 10/79-Anterior & $\begin{array}{l}\text { LVE with decreased LVF; } \\
\text { no thrombus }\end{array}$ & $\begin{array}{l}\text { Anteroapical aneurysm; } \\
\text { no thrombus }\end{array}$ & No filling defect \\
\hline 5 & $53 / M$ & Chest pain & 10/79-Anterior & $\begin{array}{l}\text { LVE with decreased LVF; } \\
\text { no thrombus }\end{array}$ & $\begin{array}{l}\text { Anteroapical aneurysm; } \\
\text { no thrombus }\end{array}$ & No filling defect \\
\hline 6 & $37 / M$ & Chest pain & 6/76-Anterior & $\begin{array}{l}\text { LVE with possible apical } \\
\text { aneurysm; no thrombus }\end{array}$ & $\begin{array}{l}\text { Anteroapical aneurysm } \\
\text { with apical thrombus }\end{array}$ & Apical filling defect $\frac{\widehat{ }}{3}$ \\
\hline 7 & $45 / M$ & Chest pain & 3/77-Anterior & $\begin{array}{l}\text { LVE with decreased LVF; } \\
\text { no thrombus }\end{array}$ & $\begin{array}{l}\text { Anteroapical aneurysm; } \\
\text { no thrombus }\end{array}$ & No filling defect \\
\hline 8 & $70 / M$ & $\begin{array}{l}\text { CHF, ventricular } \\
\text { arrhythmia }\end{array}$ & 10/79-Anterior & $\begin{array}{l}\text { LVE with decreased LVF; } \\
\text { no thrombus }\end{array}$ & $\begin{array}{l}\text { LVE with diffusely } \\
\text { decreased contractility; } \\
\text { apical thrombus }\end{array}$ & No filling defect \\
\hline 9 & $66 / F$ & CHF & 4/73-Anterior & $\begin{array}{l}\text { LVE with decreased LVF; } \\
\text { thrombus attached to } \\
\text { septum }\end{array}$ & $\begin{array}{l}\text { LVE with decreased } \\
\text { LVF; apical thrombus } \\
\text { attached to septum }\end{array}$ & $\begin{array}{l}\text { Apical filling defeçู } \\
\text { with septal } \\
\text { continuity }\end{array}$ \\
\hline 10 & $77 / M$ & Cerebral embolus & 10/79-Anterior & $\begin{array}{l}\text { Decreased septal excursion; } \\
\text { no thrombus }\end{array}$ & $\begin{array}{l}\text { Anteroapical aneurysm } \\
\text { with apical thrombus } \\
\text { extending to septum }\end{array}$ & $\begin{array}{l}\text { Apical filling defects } \\
\text { in continuity with } \\
\text { septum }\end{array}$ \\
\hline 11 & $71 / F$ & $\begin{array}{l}\text { CHF, ventricular } \\
\text { arrhythmia }\end{array}$ & 10/74-Anterior & $\begin{array}{l}\text { LVE with decreased LVF; } \\
\text { no thrombus }\end{array}$ & $\begin{array}{l}\text { Anteroapical aneurysm } \\
\text { with thrombus }\end{array}$ & Apical filling defect $\overline{\mathrm{N}}$ \\
\hline 12 & $54 / M$ & $\begin{array}{l}\text { CHF, ventricular } \\
\text { arrhythmia }\end{array}$ & 11/79-Infero-lateral & $\begin{array}{l}\text { LVE with decreased LVF; } \\
\text { no thrombus }\end{array}$ & $\begin{array}{l}\text { LVE with diffusely } \\
\text { decreased contractility; } \\
\text { apical thrombus }\end{array}$ & Apical filling defect官 \\
\hline 13 & $49 / M$ & Chest pain & $\begin{array}{l}\text { 11/79-Infero- } \\
\text { posterior }\end{array}$ & $\begin{array}{l}\text { Decreased posterior wall } \\
\text { excursion; no thrombus }\end{array}$ & $\begin{array}{l}\text { Inferior aneurysm; no } \\
\text { thrombus }\end{array}$ & $\begin{array}{l}\text { Filling defect over the } \\
\text { inferobasal area of } \\
\text { left ventricle }\end{array}$ \\
\hline 14 & $63 / M$ & Chest pain & 11/79-Inferior & $\begin{array}{l}\text { Decreased posterior wall } \\
\text { excursion }\end{array}$ & $\begin{array}{l}\text { Inferior aneurysm; no } \\
\text { thrombus }\end{array}$ & 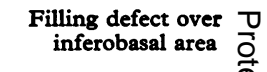 \\
\hline 15 & $60 / M$ & Chest pain & 11/79-Inferior & Normal findings; no thrombus & $\begin{array}{l}\text { Inferior aneurysm; no } \\
\text { thrombus }\end{array}$ & No filling defect \\
\hline 16 & $78 / F$ & Chest pain & 10/79-Inferior & $\begin{array}{l}\text { Decreased posterior wall } \\
\text { excursion }\end{array}$ & $\begin{array}{l}\text { Inferior aneurysm; no } \\
\text { thrombus }\end{array}$ & No filling defect \\
\hline
\end{tabular}


emboli. All patients underwent computerised tomographic scanning of the heart, M-mode echocardiography, and two-dimensional echocardiography. Eight patients were studied by left ventricular cineangiography. In five, surgical confirmation of the presence or absence of left ventricular thrombi was obtained.

\section{ECHOCARDIOGRAPHY}

$M$-mode echocardiograms were obtained using a commercially available echocardiograph (SmithKline Ekoline 20A Ultrasonoscope and $2.25 \mathrm{MHz}$

\begin{tabular}{ll}
\hline $\begin{array}{l}\text { Cineangiography } \\
\text { Anteroapical aneurysm with filling } \\
\text { defect }\end{array}$ & $\begin{array}{c}\text { Anteroapical aneurysm with old } \\
\text { organised and fresh thrombus }\end{array}$ \\
$\begin{array}{l}\text { Anteroapical aneurysm with filling } \\
\text { defect }\end{array}$ & $\begin{array}{c}\text { Anteroapical aneurysm with } \\
\text { organised and fresh thrombus }\end{array}$ \\
$\begin{array}{l}\text { Anteroapical aneurysm with apical } \\
\text { filling defect }\end{array}$ & $\begin{array}{c}\text { Anteroapical aneurysm with } \\
\text { organised and fresh thrombus }\end{array}$ \\
$\begin{array}{l}\text { Anteroapical aneurysm; no filling } \\
\text { defect }\end{array}$ & $\begin{array}{c}\text { Anteroapical aneurysm with } \\
\text { no thrombus }\end{array}$ \\
$\begin{array}{l}\text { Anteroapical aneurysm; no filling } \\
\text { defect }\end{array}$ & $\begin{array}{c}\text { Anteroapical aneurysm with } \\
\text { no thrombus }\end{array}$ \\
$\begin{array}{l}\text { Anteroapical aneurysm with apical } \\
\text { filling defect }\end{array}$ & Not done \\
\hline $\begin{array}{l}\text { Anteroapical aneurysm; no thrombus } \\
\text { Not done }\end{array}$ & Not done \\
\hline $\begin{array}{l}\text { Not done } \\
\text { contractility; no thrombus }\end{array}$ & Not done \\
\hline $\begin{array}{l}\text { Not done } \\
\text { Not done }\end{array}$ & Not done \\
\hline $\begin{array}{l}\text { Not done } \\
\text { Not done }\end{array}$ & Not done \\
\hline
\end{tabular}

transducer) interfaced with a strip chart recorder. The two-dimensional real time studies were performed with a wide-angle, $84^{\circ}$, phased-array sector scanner (Varian 3000). Both M-mode and two-dimensional real time recordings were obtained with the patient supine and in the $30^{\circ}$ left lateral position. Patients were turned into more lateral positions for apical views. Subxiphoid views were obtained with the patients supine and with knees flexed in order to obtain relaxation of abdominal muscles. The M-mode echocardiograms were obtained by positioning the transducer at the fourth or fifth intercostal space at the left sternal border, directing the ultrasonic beam so as to obtain a sweep of the left ventricle from base to apex. Twodimensional real time echocardiographic recordings were made from the left sternal border in the long and short axis as described by Kisslo et al. ${ }^{17}$ The apical and subxiphoid views were obtained with particular attention to the left ventricular apex..$^{18}{ }^{23}$ The criteria used for two-dimensional echocardiographic diagnosis of left ventricular thrombi were those described by Meltzer et al. ${ }^{21}$ The images were permanently recorded on videotape for future analysis. The illustrations of twodimensional echocardiograms in this manuscript are photographs of stop-action videotape singleframe television images.

\section{ANGIOGRAPHY}

Left ventricular cineangiograms were obtained by injecting a solution of 29.1 per cent sodium diatrizoate and 28.5 per cent meglumine diatrizoate (Renovist IIR, E R Squibb \& Sons) at a rate of $10 \mathrm{ml} / \mathrm{s}$ for 3 seconds. The projections used were $30^{\circ}$ right anterior oblique and $60^{\circ}$ left anterior oblique. Films were taken using a General Electric 9 in image intensifier, and recorded on $35 \mathrm{~mm}$ film at a rate of 60 frames/second.

\section{COMPUTERISED TOMOGRAPHY}

Computerised tomography was obtained with a third generation type scanner using a fan beam $x$-ray source rotating opposite an xenon detector array (General Electric CTT/T tomographic System). The patients were scanned in the supine position. The 4.8 second scan speed was used. The slices were $10 \mathrm{~mm}$ thick and were contiguous. Initially, a scouting series was obtained starting at the mid-chest. Approximately 10 slices were obtained in the caudal direction. These were reconstructed, and a suitable position was selected for the rapid sequence scans. Eighty to $100 \mathrm{ml}$ of a solution of meglumine diatrizoate $(52 \%)$ and sodium diatrizoate $(8 \%$ ) (Renographin-60, Squibb) were injected slowly intravenously. Scanning was 
started approximately 20 seconds after the injection of contrast media was begun. Six contiguous $1 \mathrm{~cm}$ thick slices were obtained through the region of the heart as rapidly as possible. In most cases this took approximately 150 seconds. The injection was finished just before the start of the next to last scan. The images were reconstructed and displayed on a $320 \times 320$ matrix. The cardiac structures and mural thrombi were better delineated at the window level of zero with a window width of 150 to $300(-500$ to +500 scale). The images were recorded on film by a multiformat camera.

\section{Results}

The clinical, echocardiographic, cineangiographic, and computerised tomographic features of all patients are summarised in Table 1.

\section{ECHOCARDIOGRAPHY}

Technically, optimal M-mode echocardiographic sweeps from apex to the base of the left ventricle were obtained in all patients. Only case 9 , however, had multiple, fine echoes in continuity with the interventricular septum thought to be suggestive of mural thrombus. Technically optimal twodimensional echocardiograms of the left ventricle in various projections were obtained in all patients, though the apex of the left ventricle was not completely visualised in the long and short axis projections. In only two patients could a thrombus be identified in the long axis view. No patient showed evidence of a thrombus in the short axis view. The left ventricular apex was well seen in all patients in the four and two chamber views. These views showed that eight of the 16 patients had mural thrombi. There was septal continuity of the thrombi in two patients. All eight patients were found to have absent or paradoxical systolic motion of the anteroapical areas.

\section{CINEANGIOGRA PHY}

Eight patients underwent cardiac catheterisation. All had technically satisfactory left ventricular cineangiography. Four patients showed apical filling defects consistent with mural thrombi. Septal continuity of thrombi could not be identified in any patient.

\section{SURGERY}

Three of the five patients who underwent left ventricular aneurysmectomy had large left ventricular thrombi. All thrombi were apical. In two patients septal continuity was seen. All thrombi were organised with intermingled fresh thrombotic material.

\section{COMPUTERISED TOMOGRAPHY (Fig. 1)}

Satisfactory computerised recordings were obtained on the initial attempt from all 16 patients. In 10 patients left ventricular filling defects consistent with mural thrombi were demonstrated. Six had apical defects. Two more had apical defects with septal continuity. Two had inferobasal defects. The presence or absence of left ventricular aneurysms was not well defined.

\section{CORRELATION OF FINDINGS}

From Table 2, it is apparent that both cine left ventriculography and computerised tomography correctly predicted the presence or absence of left ventricular mural thrombi in all patients who underwent surgery. In the same group, however, two-dimensional echocardiography failed to predict the presence of a thrombus in one patient (case 3 and Fig. 2), and $M$-mode echocardiography failed
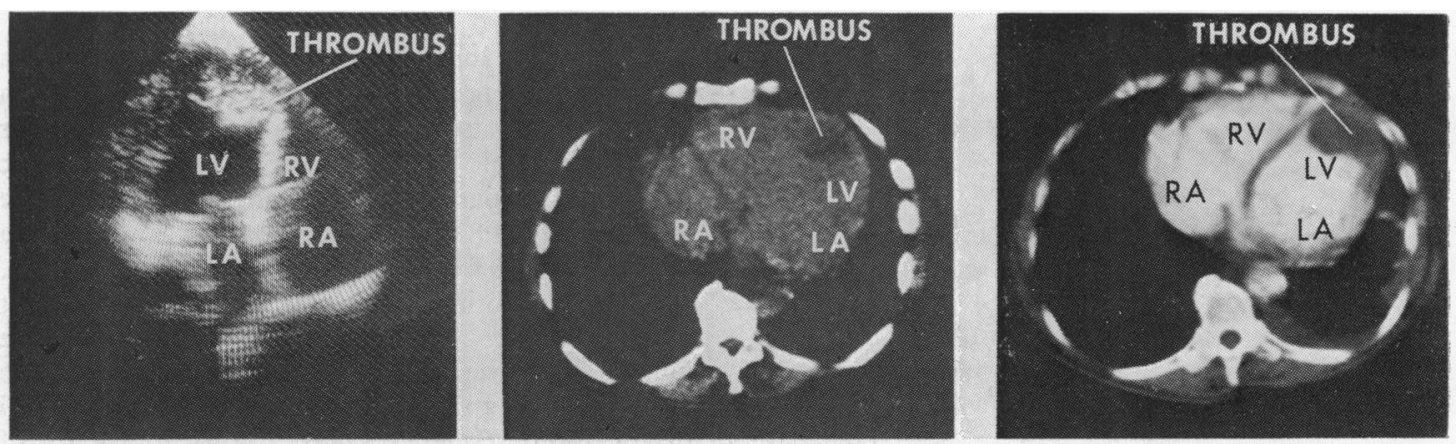

Fig. 1 Two-dimensional echocardiogram (left) and computerised tomogram with (right) and without (middle) contrast enhancement showing left ventricular apical thrombus with septal continuity. $L A$, left atrium; $L V$, left ventricle; $R A$, right atrium; $R V$, right ventricle. 
Table 2 Summary of results

\begin{tabular}{|c|c|c|c|c|c|}
\hline Case no. & M-mode echocardiography & $\begin{array}{l}\text { Two-dimensional } \\
\text { echocardiography }\end{array}$ & $\begin{array}{l}\text { Computerised } \\
\text { tomography }\end{array}$ & Cineangiography & Surgery \\
\hline 1 & - & + & + & + & + \\
\hline 3 & - & - & + & + & + \\
\hline 4 & - & - & - & - & - \\
\hline 5 & - & - & - & - & - \\
\hline 6 & - & + & + & + & \\
\hline 8 & - & $T$ & - & - & \\
\hline 9 & + & + & + & & \\
\hline 10 & - & + & + & & \\
\hline 11 & - & $\div$ & + & & \\
\hline 12 & - & + & + & & \\
\hline 13 & - & - & + & & \\
\hline 14 & - & - & + & & \\
\hline 15 & - & - & - & & \\
\hline 16 & - & - & - & & \\
\hline
\end{tabular}

+ , thrombus detected; - , thrombus not detected.
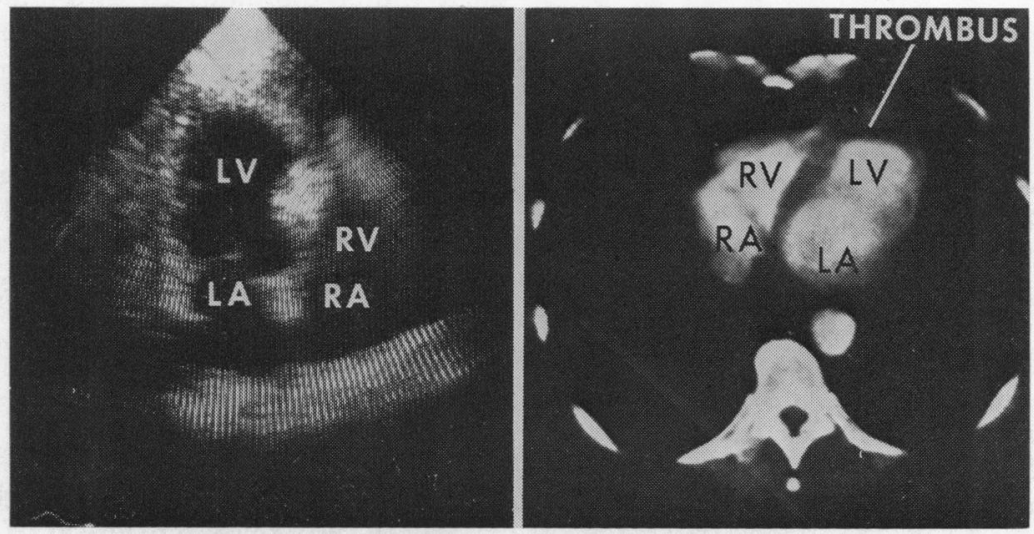

Fig. 2 Two-dimensional echocardiogram (left) and contrast enhanced computerised tomogram (right) of case 3. A distinct left ventricular apical filling defect seen in the computerised tomogram was confirmed by left ventricular cineangiogram and surgery. Two-dimensional echocardiogram failed to show apical thrombus. LA, left atrium; $L V$, left ventricle; $R A$, right atrium; $R V$, right ventricle.

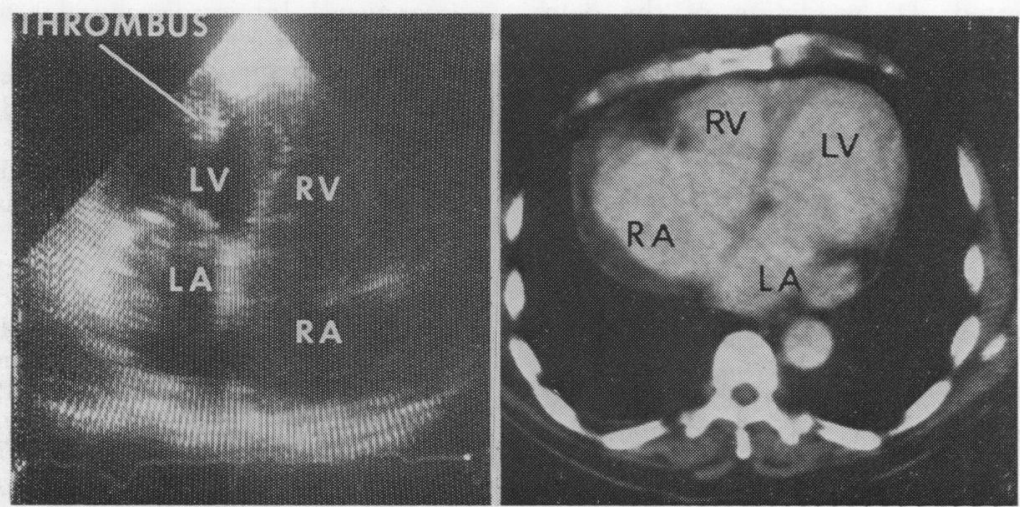

Fig. 3 Two-dimensional echocardiogram (left) and contrast enhanced computerised tomogram (right) of case 8. Note the left ventricular apical mass seen in two-dimensional echocardiogram which could not be confirmed by computerised tomography or left ventricular cineangiography. $L A$, left atrium; $L V$, left ventricle; $R A$, right atrium; $R V$, right ventricle. 
to predict the presence of thrombi in three patients (cases 1, 2, and 3). Among the 11 patients who did not undergo surgery, two (cases 13 and 14) were shown to have left ventricular mural thrombi by computerised tomography but were not identified by either M-mode or two-dimensional echocardiography. Though it is possible that these were falsepositive results, it is unlikely since both filling defects were clearly identified by computerised tomography. Two-dimensional echocardiography suggested that one patient who did not undergo surgery (case 8 ) had a left ventricular mural thrombus but this was not confirmed by either cineangiography or computerised tomography (Fig. 3). Computerised tomographic scanning delineated the filling defects more clearly than either $\mathrm{M}$-mode echocardiography or two-dimensional echocardiography.

\section{Discussion}

The sensitive capacity of computerised tomography to resolve small differences in $x$-ray attenuation makes it potentially attractive as a means of imaging the heart. ${ }^{24}{ }^{25}$ It has a high degree of reproducibility and requires only a minimal amount of technical skill. The study can be performed rapidly (total time approximately 25 minutes). Initially, the primary problem encountered in in vivo imaging of the heart by this technique was the pronounced degradation of the reconstructed image resulting from a three minute scan time and from cardiac motion. In order to obtain high resolution reconstruction, each point of the object being imaged must remain in a fixed position during rotation of the scanner. To avoid problems related to cardiac motion, three solutions have been suggested: (1) reduction of the data collection time per slice to milliseconds; (2) synchronisation of the data collection so that it occurs only at fixed points in the cardiac cycle; and (3) synchronisation of the data with the cardiac cycle after data acquisition. The last method has undergone most development ${ }^{26}$ and holds the greatest promise. Several investigators ${ }^{27} 28$ have reported studies using this technique but, to our knowledge, none has reported the imaging of left ventricular mural thrombi. Our preliminary study, the results of which are reported here, compared computerised tomography with M-mode echocardiography and two-dimensional echocardiography.

From our results, and those of others, it appears that $M$-mode echocardiography is insensitive in detecting left ventricular mural thrombi. Though some authors have been able to show that two- dimensional echocardiography is more useful, ${ }^{20} 21$ not all agree. Ports et al. ${ }^{19}$ recently reported that they were able to identify only 50 per cent of ventricular thrombi using this technique. In our study, two-dimensional echocardiography identified eight of the 10 patients shown to have left ventricular mural thrombi by computerised tomography. It failed, however, to identify left ventricular mural thrombi in three patients with clearly defined left ventricular filling defects by computerised tomography. One of these patients who underwent surgery was proved to have thrombus. Though it is possible that the results of computerised tomography in the other two patients were falsepositives, this is unlikely, since, in both cases, the filling defects were very clearly identified. Finally, one patient was identified as having a left ventricular mural thrombus by two-dimensional echocardiography which was not found by either computerised tomography (Fig. 3) or left ventricular cineangiography.

Hence, this preliminary study suggests that computerised tomography is a promising noninvasive technique for diagnosing left ventricular mural thrombi. A larger study using surgical confirmation will be necessary, however, to validate its usefulness.

\section{References}

1 Yater WM, Welsh PP, Stapleton JF, Clark ML. Comparison of clinical and pathologic aspects of coronary artery disease in men of various age groups: a study of 950 autopsied cases from the Armed Forces Institute of Pathology. Ann Intern Med 1951; 34: 352-92.

2 Jordan RA, Miller RD, Edwards JE, Parker RL. Thromboembolism in acute and healed myocardial infarction. I. Intracardiac mural thrombosis. Circulation 1952; 6: 1-6.

3 Phares WS, Edwards JE, Burchell HB. Cardiac aneurysms: clinicopathologic studies. Proc Staff Meet Mayo Clin 1953; 28: 264-71.

4 Hilden $T$, Iversen $K$, Raaschou F, Schwartz $M$. Anticoagulants in acute myocardial infarction. Lancet 1961; ii: 327-31.

5 Billig DM, Hallman GL, Cooley DA. Arterial embolism. Arch Surg 1967; 95: 1-6.

6 Thompson JE, Sigler L, Raut PS, Austin DJ, Patman RD. Arterial embolectomy: a 20 year experience with 163 cases. Surgery 1970; 67: 212-20.

7 Levy JF, Butcher HR, Jr. Arterial emboli: an analysis of 125 patients. Surgery $1970 ; 68$ : 968-73.

8 Report of the working party on anticoagulant therapy in coronary thrombosis to the Medical Research Council. Assessment of short term anticoagulant administration after cardiac infarction. $\mathrm{Br} \mathrm{Med} \mathcal{f}$ 1969 ; i: 335-42.

9 Veterans Administration Hospital Investigators. 
Anticoagulants in acute myocardial infarction. Results of a cooperative clinical trial. $\mathfrak{f} A M A$ 1973; 225: 724-9.

10 Tallury VK, DePasquale NP. Ultrasound cardiography in the diagnosis of left atrial thrombus. Chest 1971; 59: 501-3.

11 Spangler RD, Okin JT. Echocardiographic demonstration of a left atrial thrombus. Chest 1975; 67: 716-8.

12 Horgan JH, Shiel FO, Goodman AC. Demonstration of left ventricular thrombus by conventional echocardiography. $\mathcal{F} C U$ 1976; 4: 287-8.

13 Kramer NE, Rathod R, Chawla KK, Patel R, Towne WD. Echocardiographic diagnosis of left ventricular mural thrombi occurring in cardiomyopathy. Am Heart $\mathcal{F} 1978$; 96: 381-3.

14 Hamby RI, Wisoff BG, Davison ET, Harstein ML. Coronary artery disease and left ventricular mural thrombi: clinical, hemodynamic, and angiocardiographic aspects. Chest 1974 ; 66: 488-94.

15 Roelandt J, Kloster FE, TenCate FJ, et al. Multidimensional echocardiography. An appraisal of its clinical usefulness. Br Heart $\mathcal{F}$ 1974; 36: 29-43.

16 Griffith JM, Henry WL. A sector scanner for real time two-dimensional echocardiography. Circulation 1974 ; 49: 1147-52.

17 Kisslo J, Von Ramm OT, Thurstone FL. Cardiac imaging using a phased array ultrasound system. II. Clinical technique and application. Circulation 1976; 53: 262-7.

18 Silverman NH, Schiller NB. Apex echocardiography: a two-dimensional technique for evaluating congenital heart disease. Circulation 1978; 57: 50311.

19 Ports TA, Cogan J, Schiller NB, Rappaport E. Echocardiography of left ventricular masses. Circulation 1978; 58: 528-36.
20 DeMaria AN, Bommer W, Neumann A, et al. Left ventricular thombi identified by cross-sectional echocardiography. Ann Intern Med 1979; 90: 14-8.

21 Meltzer RS, Guthaner D, Rakowski H, Popp RL, Martin RP. Diagnosis of left ventricular thrombi by two-dimensional echocardiography. $\mathrm{Br}$ Heart $\mathfrak{f}$ 1979; 42: 261-5.

22 Mikell FL, Asinger RW, Rourke T, Hodges M, Sharma B, Francis GS. Two-dimensional echocardiographic demonstration of left atrial thrombi in patients with prosthetic mitral valves. Circulation 1979; 60: 1183-90.

23 Chang S, Feigenbaum H, Dillon J. Subxiphoid echocardiography. Chest 1975; 68: 233-5.

24 Adams DF, Hessel SJ, Judy PF, Stein JA, Abrams HL. Computed tomography of the normal and infarcted myocardium. $A \mathcal{F} R$ 1976; 126: 786-91.

25 Powell WJ, Jr, Wittenberg J, Maturi RA, Dinsmore RE, Miller SW. Detection of edema associated with myocardial ischemia by computerized tomography in isolated, arrested canine hearts. Circulation 1977; 55: $99-108$.

26 Harell GS, Guthaner DF, Breiman RS, et al. Stop-action cardiac computed tomography. Radiology 1977; 123: 515-7.

27 Ter-Pogossian MM, Weiss ES, Coleman RE, Sobel BE. Computed tomography of the heart. $A \mathcal{F} R$ 1976; 127: 79-90.

28 Lipton $\mathrm{MJ}$, Brundage $\mathrm{BH}$, Doherty $\mathrm{PW}$, et al. Contrast medium-enhanced computed tomography for evaluating ischemic heart disease. Cardiovasc Med 1979; 4 : 1219-29.

Requests for reprints to Dr Chandra $\mathrm{K}$ Nair, Creighton University Cardiac Center, 601 No. 30th Street, Omaha, Nebraska 68131, USA. 